Pesq. Vet. Bras. 38(1):189-194, janeiro 2018

DOI: $10.1590 / \mathrm{S} 0100-736 \mathrm{X} 2018000100029$

\title{
Biochemical parameters of the giant anteater (Myrmecophaga tridactyla Linnaeus, 1758) of the Brazilian Cerrado ${ }^{1}$
}

\author{
Evelyn de Oliveira ${ }^{2}$, Laura G. Vila², Thays de C. Trentin ${ }^{3}$, Tiago de O. Jubé ${ }^{4}$ \\ and Danieli B. Martins ${ }^{5 *}$
}

\begin{abstract}
Oliveira E., Vila L.G., Trentin T.C., Jubé T.O. \& Martins D.B. 2018. Biochemical parameters of the giant anteater (Myrmecophaga tridactyla Linnaeus, 1758) of the Brazilian Cerrado. Pesquisa Veterinária Brasileira 38(1):189-194. Laboratório Clínico Veterinário, Hospital Veterinário, Departamento de Medicina Veterinária, Escola de Veterinária e Zootecnia, Universidade Federal de Goiás, Rodovia Goiânia Km 8, Campus Samambaia, Goiânia, G0 74001-970, Brazil. E-mail: vetdanielimartins@yahoo.com.br

The giant anteater (Myrmecophaga tridactyla) is classified as a vulnerable species on Brazil's list of species at risk of extinction mainly due to deforestation and forest fires. This has contributed to a considerable increase in detailed clinical case records of the treatment of wild species at veterinary institutions. However, the paucity of serum biochemical profiles of healthy giant anteaters has made it difficult to evaluate these animals, preventing diagnosis, treatment and prognosis. The objective of this work was to collect data about the biochemical profile of healthy giant anteaters from the Brazilian Cerrado raised in captivity, in order to better understand the physiological characteristics inherent to this species. Eighteen analytes from 12 healthy giant anteaters were measured. The following means and standard deviations were found in the biochemical analyses: albu$\min 3.29 \pm 0.33 \mathrm{~g} / \mathrm{dL}$, ALT $15.49 \pm 7.98 \mathrm{IU} / \mathrm{L}$, amylase $1037.92 \pm 149.04 \mathrm{IU} / \mathrm{L}$, AST $21,12 \pm 7.50$ $\mathrm{IU} / \mathrm{L}$, total cholesterol $62.79 \pm 20.08 \mathrm{mg} / \mathrm{dL}$, HDL cholesterol $14.73 \pm 4.98 \mathrm{mg} / \mathrm{dL}$, LDL cholesterol $26.60 \pm 11.05 \mathrm{mg} / \mathrm{dL}$, VLDL cholesterol $2.14 \pm 1.06 \mathrm{mg} / \mathrm{dL}, \mathrm{CK} 111.61 \pm 70.16 \mathrm{IU} / \mathrm{L}$, creatinine $1.05 \pm 0.37 \mathrm{mg} / \mathrm{dL}$, iron $194.64 \pm 81.17 \mu \mathrm{g} / \mathrm{dL}$, GGT $65.18 \pm 54.57 \mathrm{IU} / \mathrm{L}$, glucose $103.71 \pm 29.63 \mathrm{mg} / \mathrm{dL}$, globulins $2.76 \pm 0.36 \mathrm{~g} / \mathrm{dL}$, lipase $28.80 \pm 5.11 \mathrm{IU} / \mathrm{L}, \mathrm{TSP} 6.05 \pm 0.56 \mathrm{~g} /$ $\mathrm{dL}$, triglycerides $10.71 \pm 5.29 \mathrm{mg} / \mathrm{dL}$, and urea $53.46 \pm 18.28 \mathrm{mg} / \mathrm{dL}$. The values found in this study can be used as references for the laboratory evaluation of giant anteaters living in conditions similar to those of this study. This is one of the first reports of biochemical examinations on giant anteaters of the Cerrado biome.
\end{abstract}

INDEX TERMS: Biochemistry, giant anteater, Myrmecophaga tridactyla, Brazil, Cerrado, serum biochemistry profile, glucose, lipid profile, Xenarthra.

\footnotetext{
${ }^{1}$ Received on February 22, 2017.

Accepted for publication on June 30, 2017.

Parte da dissertação de mestrado do primeiro autor.

${ }^{2}$ Programa de Pós-Graduação em Ciência Animal (PPGCA), área de concentração em Patologia, Clínica e Cirurgia Animal, Escola de Veterinária e Zootecnia (EVZ), Universidade Federal de Goiás (UFG), Rodovia Goiânia Km 8, Campus Samambaia, Goiânia, GO 74001-970, Brazil.

${ }^{3}$ Programa de Residência Profissional em área da Saúde: Patologia Clínica Veterinária, EVZ/UFG, Rodovia Goiânia Km 8, Campus Samambaia, Goiânia, GO 74001-970, Brazil.

${ }^{4}$ Programa de Residência Profissional em área da Saúde: Toxicologia Veterinária, EVZ/UFG, Rodovia Goiânia Km 8, Campus Samambaia, Goiânia, GO 74001-970, Brazil.

${ }^{5}$ Departamento de Medicina Veterinária, EVZ/UFG, Rodovia Goiânia Km 8, Campus Samambaia, Goiânia, GO 74001-970, Brazil. *Corresponding author: vetdanielimartins@yahoo.com.br
}

RESUMO.- [Parâmetros bioquímicos de tamanduás-bandeiras (Myrmecophaga tridactyla Linnaeus, 1758) do cerrado brasileiro.] 0 tamanduá-bandeira (Myrmecophaga tridactyla) está classificado como espécie vulnerável na lista brasileira de espécies ameaçadas de extinção devido principalmente ao desmatamento e aos incêndios florestais. Tal fato contribuiu com o aumento da casuística de atendimento de espécies silvestres em instituições veterinárias. Porém, a escassez de valores bioquímicos séricos em tamanduás-bandeiras hígidos tem dificultado a avaliação destes animais, impedindo o diagnóstico, tratamento e prognóstico. 0 objetivo deste trabalho foi fornecer dados sobre o perfil bioquímico de tamanduás-bandeiras saudáveis do cerrado brasileiro, criados em cativeiro, a fim de compreender me- 
lhor as características fisiológicas inerentes a esta espécie. Foram mensurados 18 analitos de 12 tamanduás-bandeiras hígidos. As médias e o desvio padrão correspondentes às análises bioquímicas foram: albumina 3,29 $\pm 0,33 \mathrm{~g} / \mathrm{dL}$; ALT 15,49 $\pm 7,98 \mathrm{UI} / \mathrm{L}$; amilase 1037,92 $\pm 149,04 \mathrm{UI} / \mathrm{L} ;$ AST 21, $12 \pm 7,50 \mathrm{UI} / \mathrm{L}$; colesterol total $62,79 \pm 20,08 \mathrm{mg} / \mathrm{dL}$; colesterol

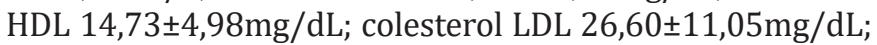
colesterol VLDL 2,14 $\pm 1,06 \mathrm{mg} / \mathrm{dL}$; CK 111,61 $\pm 70,16 \mathrm{UI} / \mathrm{L}$; creatinina $1,05 \pm 0,37 \mathrm{mg} / \mathrm{dL}$; ferro $194,64 \pm 81,17 \mu \mathrm{g} / \mathrm{dL} ; \mathrm{GGT}$ 65,18 $\pm 54,57 \mathrm{UI} / \mathrm{L} ;$ glicose 103,71 $\pm 29,63 \mathrm{mg} / \mathrm{dL}$; globulinas

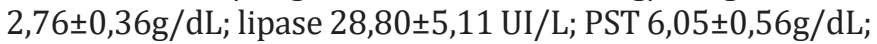

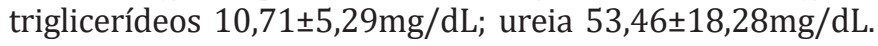
Os valores encontrados neste estudo podem ser utilizados como referência para a avaliação laboratorial de tamanduás-bandeiras que vivam em condições similares ao do presente estudo. Este é um dos primeiros estudos a relatar exames bioquímicos em tamanduás-bandeiras do bioma cerrado.

TERMOS DE INDEXAÇÃO: Tamanduá-bandeira, Myrmecophaga tridactyla, Cerrado, bioquímica sérica, glicose, lipidograma, Xenarthras.

\section{INTRODUCTION}

Despite its wide geographic distribution, the giant anteater is classified as a vulnerable species on the Brazilian list of species at risk of extinction (Miranda et al. 2014). This fact is basically associated with the changes the Cerrado has undergone in the development of agriculture, which have significantly reduced the giant anteater population in this biome (Lacerda et al. 2009, Cáceres et al. 2010). Other factors such as deforestation, forest fires and wildlife roadkill strongly affect the populations of several species, and the giant anteater is one of the main mammalian victims of wildfires (Cáceres et al. 2010, Superina et al. 2010).

This has led to a considerable increase in detailed clinical case records of the treatment of wild species at veterinary institutions. However, the laboratory diagnosis of diseases that affect these animals is hindered by the difficulty of sampling, which is a laboratory technique that is unsuitable for small volumes, and mainly due to the absence of regional reference values for comparison (Wendt et al. 2015). The paucity of such data makes the clinical evaluation of animals difficult, since the performance of complementary tests is a limiting factor for the diagnosis of diseases (Madella et al. 2006). Therefore, the determination of reference intervals for a given species is essential (Delgado et al. 2011, Nucci et al. 2014).

Laboratory tests are important because they provide significant information about morphofunctional aspects of various organs, which, allied to clinical medicine, help in disease detection (Diniz et al. 1995, Stockham \& Scott 2011). Therefore, an increasing number of studies have focused on the biochemical profile of wild animals, aiming to identify the most specific analytes for a more accurate evaluation of these species (Madella et al. 2006, Delgado et al. 2011, Nucci et al. 2014).

In view of the above, this study aimed to determine the biochemical profile of healthy giant anteaters of the Brazilian Cerrado, raised in captivity, in order to better understand the physiological characteristics inherent to this species and to provide reference data. Such information contributes to the interpretation of laboratory tests performed on this species, thus facilitating the evaluation of the health status of these animals and monitoring of their sanitary conditions (Nucci et al. 2014).

\section{MATERIALS AND METHODS}

This study involved 12 giant anteaters (seven females and five males) from the Brazilian Cerrado, kept in captivity at the Brasilia Zoo Foundation (DF). The study was approved by the Ethics Committee on Animal Use of the Federal University of Goiás (CEUA/ UFG) under no. 122/2014, and was authorized by the Biodiversity Authorization and Information System (SISBIO/IBAMA) under no. 02010.001283/2014-27.

Before collecting blood samples, the animals were chemically restrained by injecting ketamine hydrochloride and midazolam maleate to induce anesthesia, and isoflurane to maintain it.

Blood was collected by jugular venipuncture, using $10 \mathrm{~mL}$ syringes and $25 \mathrm{x} 8$ gauge needles $\left(\mathrm{BD}^{\circledR}\right.$, Becton Dickinson, São Paulo, Brazil), and was transferred to tubes without anticoagulant, containing separator gel to obtain serum; while a small amount was transferred to pediatric tubes (BD Microtainer ${ }^{\circledR}$ ) containing sodium fluoride and EDTA to determine blood glucose levels. Immediately after the blood was drawn, the tubes were centrifuged for five minutes at a rotation of $2318 \mathrm{G}$ to obtain the plasma. The serum was obtained after clot retraction, when the blood was centrifuged for 10 minutes at the same rotational speed. The supernatant from both tubes was divided into aliquots, stored in properly labeled Eppendorf tubes, and then frozen to a temperature of $-20^{\circ} \mathrm{C}$.

A week after the blood was collected, biochemical analyses were performed at the Laboratory of Clinical Pathology of the Veterinary Hospital of the Federal University of Goiás (LabClin Vet-HV-UFG). Albumin and total serum protein (TSP) were determined using commercial reagents from Biotécnica ${ }^{\circledR}$ (Biotécnica Indústria e Comércio Ltda., Varginha, MG, Brazil).The other analytes were determined using commercial reagents from Labtest $^{\circledR}$ (Labtest Diagnóstica S.A., Lagoa Santa, MG, Brazil), based on a kinetic and colorimetric method, at a temperature of $37^{\circ} \mathrm{C}$, with reading performed in a $\mathrm{CM} 250^{\circledR}$ automatic biochemistry analyzer (Wiener Lab Group, Rosario, Argentina).

The biochemical profiling involved the following procedures. Measurement of albumin, TSP and high-density lipoprotein (HDL) cholesterol (end-point reaction, using bromocresol green, biuret and precipitation with phosphotungstic acid and magnesium chloride, respectively). Measurements were taken of serum activity of ALT, AST and CK (using kinetic methods proposed by the International Federation of Clinical Chemistry and Laboratory Medicine (IFCC)); amylase (by a kinetic method of the chromogenic substrate 1,4-galactopyranosyl-maltoside); total cholesterol, glucose and triglycerides (using the Trinder technique with end-point reading, catalyzed by the enzymes esterase oxidase, glucose oxidase and oxidase, respectively); iron (modified Goodwin method); alkaline phosphatase (modified Bowers and McComb method); creatinine (picrate method without precipitation), GGT (modified Szasz kinetic method); urea, lipase (enzymatic method), and low-density lipoprotein (LDL) cholesterol (selective surfactant method). Globulin levels were determined by subtracting albumin from total protein levels, while very low-density lipoprotein (VLDL) cholesterol was determined by the Friedewald equation, and corresponded to one fifth of the triglycerides.

The analytes were measured in duplicate, and the final result represents their average values. All the results were recorded on a table for subsequent analysis as well as for the determination of their standard deviation and means. 
Table 1. Biochemical data (means and standard deviation) obtained from

12 healthy captive giant anteaters (Myrmecophaga tridactyla) from the

Cerrado biome, compared with data from two other studies involving the same species but from different locations

\begin{tabular}{lccc}
\hline $\begin{array}{c}\text { Location and lifestyle } \\
\text { Biochemical parameter }\end{array}$ & $\begin{array}{c}\text { Brazilian Cerrado, } \\
\text { in captivity } \\
\text { (this study) }\end{array}$ & $\begin{array}{c}\text { São Paulo, } \\
\text { in captivity } \\
\text { (Satake 2002) }\end{array}$ & $\begin{array}{c}\text { Argentina, } \\
\text { in captivity } \\
\text { (Nucci et al. 2014) }\end{array}$ \\
\hline Albumin (g/dL) & $3.29 \pm 0.33$ & $1.48 \pm 0.03$ & $3.62 \pm 0.508$ \\
ALT (IU/L) & $15.49 \pm 7.98$ & $30.58 \pm 3.48$ & $42.0 \pm 15.19$ \\
Amylase (IU/L) & $1037.92 \pm 149.04$ & $681.26 \pm 31.34$ & $1018 \pm 309.6$ \\
AST (IU/L) & $21.12 \pm 7.50$ & $45.62 \pm 3.50$ & $35.8 \pm 10.79$ \\
Total cholesterol (mg/dL) & $62.79 \pm 20.08$ & $83.94 \pm 4.58$ & $93.1 \pm 19.70$ \\
HDL cholesterol (mg/dL) & $14.73 \pm 4.98$ & - & - \\
LDL cholesterol (mg/dL) & $26.60 \pm 11.05$ & - & - \\
VLDL cholesterol (mg/dL) & $2.14 \pm 1.06$ & - & - \\
CK (IU/L) & $111.61 \pm 70.16$ & $122.28 \pm 11.34$ & $171.7 \pm 67.26$ \\
Creatinine (mg/dL) & $1.05 \pm 0.37$ & $1.13 \pm 0.046$ & $1.17 \pm 0.631$ \\
Iron ( $\mu$ g/dL) & $194.64 \pm 81.17$ & - & $136.9 \pm 26.25$ \\
GGT (IU/L) & $65.18 \pm 54.57$ & $74.51 \pm 14.31$ & $24.3 \pm 21.56$ \\
Glucose (mg/dL) & $103.71 \pm 29.63$ & - & - \\
Globulins (g/dL) & $2.76 \pm 0.36$ & - & - \\
Lipase (IU/L) & $28.80 \pm 5.11$ & - & $35 \pm 19.5$ \\
TSP (g/dL) & $6.05 \pm 0.56$ & $6.98 \pm 0.12$ & $7.66 \pm 1.085$ \\
Triglycerides (mg/dL) & $10.71 \pm 5.29$ & - & $16.3 \pm 10.12$ \\
Urea (mg/dL) & $53.46 \pm 18.28$ & $36.17 \pm 1.87$ & $40.3 \pm 15.95$
\end{tabular}

\section{RESULTS}

Table 1 lists the mean values and standard deviation of the biochemical tests of the healthy giant anteaters of the Cerrado biome. The data obtained here were compared with two other studies that also involved the same species in captivity, albeit from other locations.

\section{DISCUSSION}

Reports on the biochemical profiles of giant anteaters are scanty (Nucci et al. 2014, Satake 2002), and this is the first study involving this species from the Brazilian Cerrado, as well as the first to determine the animal's lipid profile and measure its glucose levels. Since most giant anteaters live in this biome, it is of paramount importance to determine reference values for the species in this region (Miranda et al. 2014).

Because they are wild animals, they must be physically and/or chemically restrained before blood can be drawn, and this may interfere in laboratory results (Tryland 2006). Therefore, the restraint protocol to be used on these animals must be considered so as to avoid possible interference in laboratory tests (Batista et al. 2009, Picioli et al. 2013, Vila 2015). The giant anteaters in this study were restrained using ketamine hydrochloride, midazolam maleate and isoflurano (West et al. 2014), since we found no reports about the possible interference of these drugs in biochemical tests of this species.

The increased serum level of a given analyte indicates some cellular dysfunction or damage of the organ where it is produced, stored or simply eliminated. However, there are cases in which a decrease in one or more of these analytes also provides important information about the functioning of organs (Alvarez \& Whittemore 2009, Contreras-Zentella \& Hernández-Muñoz 2016).

Several analytes can be quantified to assess the liver. However, some are more commonly used; the ALT and
AST enzymes are indicated for morphological analysis of the liver (hepatocytes), and the enzymes ALP and GGT to check for cholestasis (Opara et al. 2006, Contreras-Zentella \& Hernández-Muñoz 2016). The mean ALT and AST levels found in this study were lower than those previously reported for the species, while the GGT levels were higher. This indicates that giant anteaters living in other biomes have different physiological values, which may lead to errors in evaluations if they are used as reference. This reinforces the importance of reference parameters for animals that present a maximum similarity between physiological, dietary and environmental factors (Rafaj et al. 2011).

The kidneys of mammals can be evaluated primarily by measuring urea and creatinine, which is more specific because it is not influenced by protein metabolism or other external factors. Because they are eliminated exclusively by the kidneys, the increase in these metabolites suggests a failure in renal function (Menezes et al. 2010). The mean creatinine levels were very similar to those proposed previously, indicating that several extrinsic factors such as location, time of year and nutritional status of these animals did not interfere in the serum levels of this analyte. However, the mean urea levels were slightly higher than the others and may be related to the diet and protein metabolism of these animals (Chizzotti et al. 2007). Due to the lack of nutritional data on the species from other locations, a correlation cannot be inferred between the serum level of urea of the latter with those of this study.

The determination of albumin, globulins and TSP provides important information about the nutritional, immune and hydration status of animals. Low albumin levels are related to malnutrition or decreased protein intake, renal loss, gastroenteritis, a chronic inflammatory process, or severe liver disease. Elevated serum globulins indicates an exacerbated production of acute-phase proteins by the 
liver or of immunoglobulins by B lymphocytes (Nunes et al. 2010). A relative increase in the TSP concentration occurs mainly in cases of dehydration, in which all the protein fractions increase in the same proportion (Eckersall 2008), or in cases of inflammation or infection, when there is augmented globulin production (Rodrigues et al. 2007).

The mean albumin levels were similar to those found by Nucci et al. (2014) and higher than those proposed by Satake (2002). This discrepancy may be attributed to the type of diet (Silva et al. 2010), since the giant anteaters in this and the other studies lived in captivity. The crude protein content ingested by the animals in this study was 29.2\%. However, the lack of information about the diet of the animals involved in other studies makes it difficult to correlate the diet with measured albumin levels (González \& Scheffer 2003, Nucci et al. 2014). As for globulins, which are an integral part of TSP levels, there are no reports of this protein fraction in giant anteaters. Given its importance in determining the existence of inflammatory processes and evaluating the immunological status (Silva et al. 2008), the quantitative determination of this group is relevant.

Lipids play several roles in the body, acting primarily as hormones or serving as a substrate for their production, as energy reserve, thermal insulation, in the transport of vitamins and as constituents of biomembranes. The most important lipids, which are usually measured in the clinical routine, are total cholesterol and its fractions (HDL, LDL and VLDL) and triglycerides. The increase of these analytes may be related to the diet consumed by these animals, to excessive hepatic production, or to some endocrine disorder (Fernandes et al. 2012, Radin 2015).

This is the first research to determine HDL, LDL and VLDL reference values in giant anteaters. Because lipoproteins are essential for lipid metabolism, since they are responsible for the transport of cholesterol and triglycerides, knowledge about their levels in healthy animals is required, especially when evaluating their nutritional status (Delmondes et al. 2014). The other esters (triglycerides and total cholesterol) have already been reported in other studies of this species (Satake 2002, Nucci et al. 2014). However, the mean levels of both triglycerides and total cholesterol found in this present study were lower than those previously reported. This difference in levels may be attributed to factors such as age, since younger animals tend to have higher levels of these analytes, sex, or even diet (Fernandes et al. 2012).

Several laboratory tests can be performed for the exogenous evaluation of pancreas, be it to detect parenchymal lesions or to identify pancreatic insufficiency. The enzymes usually measured in a pet clinic when pancreatic damage is suspected are amylase and lipase (Bellier 2010), but because this disease is difficult to diagnose, this evaluation is more complex in wild animals (Guilloteau et al. 2012). Although further studies on the physiology of this gland in giant anteaters are needed, it is important to know the reference values of these enzymes, since it is helpful in the diagnosis when there is clinical suspicion of pancreatic alterations.
Amylase levels in anteaters have been reported previously, and although our findings differed from those of Satake (2002), they were similar to those reported by Nucci et al. (2014). However, there are no reports of lipase levels in anteater species in Brazil. Because these enzymes are highly unstable, several factors interfere in their measurement. However, in cases of acute pancreatitis, their serum levels may increase up to fourfold from baseline levels, indicating inflammation, and lipase is more specific than amylase (Thomasset \& Carter 2016).

There are no previous reports about reference levels of blood glucose in giant anteaters. This information is extremely relevant, since it pertains to several organs involved in the mechanisms of plasma glucose regulation, such as the liver, pancreas and kidneys, and also indicates any pathophysiological disorder related to a glycemic imbalance, as in the case of animals in shock (Ballian et al. 2010). The range found in this study is similar to those reported for dogs, cats, horses, pigs, llamas and monkeys (Kaneko 2008). Knowledge about this biochemical parameter in healthy animals is of great value, since animals in critical condition, such as burn victims, show changes in carbohydrate metabolism due to glucose intolerance and peripheral resistance to insulin, causing significant variations in the plasma levels of this carbohydrate (Ballian et al. 2010).

The enzyme CK is located almost exclusively in the cytoplasm of muscle cells and has a relatively short half-life. Its increase is therefore related to acute muscle injury, particularly of skeletal muscles and rarely of cardiac and smooth muscle (Dias et al. 2011). The levels found in this study were similar to previously reported ones (Satake 2002, Nucci et al. 2014). Physiological factors such as sex, age and muscle mass may interfere in serum levels of CK (Foschini et al. 2007). However, no differences were observed between the serum levels of this enzyme in the male and female giant anteaters of this study. The mean weight of these animals was $36.6 \mathrm{~kg}$, and the lightest and heaviest specimens ( 30.5 and $49.3 \mathrm{~kg}$ respectively) showed the same CK levels.

Iron is a micronutrient essential to the organism because it is involved in several functions, such as oxygen transport (hemoglobin), the composition of several proteins and enzymes such as myoglobin, cytochromes, catalases and ribonucleotide reductase, aiding in cellular respiration and DNA synthesis (Dunn et al. 2007). Nucci et al. (2014) reported serum iron levels in giant anteaters in Argentina, but to date no such levels have been reported for the species in Brazil. The iron levels found in this study are higher than those reported previously, and may be attributed not only to the physiological needs of each animal, since the absorption of this mineral is regulated by the body's needs, but also to the diet fed to these animals (Grotto 2008).

Given the importance of biochemical tests in the clinical treatment of wild animals, this study contributes to the welfare and conservation of both captive and free-living giant anteaters. It should be noted that to attest to the health status of these animals requires not only a clinical examination but also the correct interpretation of laboratory 
data in the light of ideal parameters (Opara et al. 2006, Delgado et al. 2011).

\section{CONCLUSIONS}

The analyte levels measured in captive giant anteaters from the Brazilian Cerrado can be used as reference for the laboratory assessment of the same species living in conditions similar to those of this study. The biochemical parameters measured here differ from those found in previous studies involving giant anteaters from different locations. These differences may be ascribed to physiological, environmental, climate and dietary conditions.

Therefore, given that this is one of the first studies to report about biochemical tests on giant anteaters of the Cerrado biome, the findings reported here can be effectively used as parameters for the biochemical evaluation of giant anteaters.

Acknowledgements.- This work was carried out with the financial support of CNPq (Brazil's National Council for Scientific and Technological Development (Universal Notice no. 459052/2014-4). E.O. thanks CAPES (Brazil's Federal Agency for the Support and Improvement of Higher Education) for granting scholarship. All the authors thank the Brasilia Zoo for providing institutional support.

Conflict of interest statement.- The authors have no competing interests.

\section{REFERENCES}

Alvarez L. \& Whittemore J.C. 2009. Liver enzyme elevations in dogs: physiology and pathophysiology. Compend. Contin. Educ. Vet. 31:408-414.

Ballian N., Rabiee A., Andersen D.K., Elahi D. \& Gibson B.R. 2010. Glucose metabolism in burn patients: the role of insulin and other endocrine hormones. Burns 36:599-605.

Batista J.S., Bezerra F.S.B., Agra E.G.D., Calado E.B., Godói R.M., Rodrigues C.M.F., Nunes F.C.R. \& Blanco B.S. 2009. Efeitos da contenção física e química sobre os parâmetros indicadores de estresse em catetos (Tayassu tajacu). Acta Vet. Brasilica 3:92-97.

Bellier S. 2010. Interprétation et valeurs usuelles des paramètres sanguins en biochimie clinique vétérinaire. Revue Francophone des Laboratoires 2010:43-56.

Cáceres N.C., Hannibal W., Freitas D.R., Silva E.L., Roman C. \& Casella J. 2010. Mammal occurrence and roadkill in two adjacent ecoregions (Atlantic Forest and Cerrado) in south-western Brazil. Zoology 27:709-717.

Chizzotti M.L., Valadares Filho S.C., Valadares R.F.D., Chizzotti F.H.M., Marcondes M.I. \& Fonseca M.A. 2007. Consumo, digestibilidade e excreção de ureia e derivados de purinas em vacas de diferentes níveis de produção de leite. Revta Bras. Zootec. 36:138-146.

Contreras-Zentella M.L. \& Hernández-Muñoz R. 2016. Is liver enzyme release really associated with cell necrosis induced by oxidant stress? Oxid. Med. Cell. Longev. 2016:1-12.

Delgado C., Valente A., Quaresma I., Costa M. \& Dellinger T. 2011. Blood biochemistry reference values for wild juvenile loggerhead sea turtles (Caretta caretta) from Madeira archipelago. J. Wildl. Dis. 47:523-529.

Delmondes P.H., Hamerski T.L. \& Cardoso G. 2014. Perfil lipídico de uma equipe de atletismo do município de Barra do Garças/MT. Revta Eletrôn. Interdisciplinar 1:56-60.

Dias D.C.R., Rocha J.S., Mello F.M., El-Bachá R.S. \& Ayres M.C.C. 2011. Influência do exercício sobre o hemograma, enzimas marcadoras de lesão muscular e índice de peroxidação de biomoléculas em equinos submetidos à atividade de salto. Revta Bras. Ciênc. Vet. 18:36-42.

Diniz L.S., Costa E.O. \& Oliveira P.M. 1995. Clinical disorders observed in anteaters (Myrmecophagidae, Edentata) in captivity. Vet. Res. Commun. 19:409-415.
Dunn L.L., Rahmanto Y.S. \& Richardson D.R. 2007. Iron uptake and metabolism in the new Millennium. Trends Cell Biol. 17:93-100.

Eckersall P.D. 2008. Proteins, proteomics and the dysproteinemias, p.117155. In: Kaneko J.J., Harvey J.W. \& Bruss M.L. (Eds), Clinical Biochemistry of Domestic Animals. 6th ed. Academic Press, Burlington.

Fernandes S.R., Freitas J.A., Souza D.F., Kowalski L.H., Dittrich R.L., Junior P.R. \& Silva C.J.A. 2012. Lipidograma como ferramenta na avaliação do metabolismo energético em ruminantes. Revta Bras. Agrociênc. 18:2132.

Foschini D., Prestes J. \& Charro M.A. 2007. Relação entre exercício físico, dano muscular e dor muscular de início tardio. Revta Bras. Cineantropometria Desempenho Humano 9:101-106.

González F.H.D. \& Scheffer J.F.S. 2003. Perfil sanguíneo: ferramenta de análise clínica, metabólica e nutricional. Anais I Simpósio de Patologia Clínica Veterinária da Região Sul do Brasil, Porto Alegre, p.73-89.

Grotto H.Z. 2008. Iron metabolism: an overview on the main mechanisms involved in its homeostasis. Revta Bras. Hematol. Hemoter. 30: 390-397.

Guilloteau P., Vitari F., Metzinger-Le Meuth V., Le Normand L., Romé V., Savary G., Delaby L., Domeneghini C. \& Morisset J. 2012. Is there adaptation of the exocrine pancreas in wild animal? The case of the Roe deer. BMC Vet. Res. 8:70.

Kaneko J.J. 2008. Carbohydrate metabolism and its diseases, p.45-80. In: Kaneko J.J., Harvey J.W. \& Bruss M.L. (Eds), Clinical Biochemistry of Domestic Animals. 6th ed. Academic Press, Burlington.

Lacerda A.C.R., Tomas W.M. \& Marinho-Filho J. 2009. Domestic dogs as an edge effect in the Brasília National Park, Brazil: interactions with native mammals. Anim. Conserv. 12:477-487.

Madella D.A., Rodrigues Neto E.J., Felisberto M.E. \& Souza C.E. 2006. Valores hematológicos de capivaras (Hydrochoerus hydrochaeris Rodentia: Hydrochoeridae) de vida livre na região de Campinas-SP. Ciência Rural 36:1321-1324.

Menezes L.B., Fioravanti M.C.S., Silva M.S.B., Franco L.G., Sales T.P., Andrascko M.M., Veado J.C.V. \& Araújo E.G. 2010. Avaliação do efeito da clorpromazina sobre a função renal de cães submetidos à isquemia e reperfusão. Pesq. Vet. Bras. 30:108-114.

Miranda F.R., Chiarello A.G., Rohe F., Braga F.G., Mourão Gd.M. \& Miranda G.H.B. 2014. Avaliação do risco de extinção de Myrmecophaga tridactyla Linnaeus, 1758 no Brasil, p.89-106. In: ICMBio. ICMdCdB (Eds), Avaliação do Risco de Extinção de Xenartros Brasileiros. Ministério do Meio Ambiente, Brasília.

Nucci D.L.D., Marc L.B., Jimeno G.P., Scapini J.P. \& Masso R.J.D. 2014. Hematology and serum biochemistry values in captive giant anteaters (Myrmecophaga tridactyla) in Argentina. Edentata 15:39-51.

Nunes A.S., Oliveira R.L., Ayres M.C.C., Bagaldo A.R., Garcez Neto A.F. \& Barbosa L.P. 2010. Condição hepática de cordeiros mantidos com dietas contendo torta de dendê proveniente da produção de biodiesel. Revta Bras. Zootec. 39:1825-1831.

Opara M.N., Ike K.A. \& Okoli I.C. 2006. Haematology and plasma biochemistry of the wild adult African grasscutter (Thryonomis swinderianus, Temminck). J. Am. Sci. 2:17-22.

Picioli A., Martini M.V., Minervino A.H., Dias L.G. \& Junior E.M. 2013. Uso da acepromazina, dexmedetomidina e xilazina na sedação em cães: alterações hematológicas e bioquímicas. Revta Bras. Ciênc. Vet. 20:1319.

Radin M.J. 2015. Avaliação laboratorial dos lipídios, p.416-430. In: Thrall M.A., Weiser G., Allison R.W. \& Campbell T.W. (Eds), Hematologia e Bioquímica Clínica Veterinária. Editora Roca, São Paulo.

Rafaj R.B., Toncic J., Vickovic I. \& Sostaric B. 2011. Haematological and biochemical values of farmed red deer (Cervus elaphus). Veterinarski Arhiv 81:513-523.

Rodrigues A.M., Zanutto M.D. \& Hagiwara M.K. 2007. Concentrações séricas de proteína total, albumina e gamaglobulinas em gatos infectados pelo vírus da imunodeficiência felina. Ciência Rural 37:153-158.

Satake F. 2002. Hemograma e constituintes bioquímicos do sangue de tamanduás-bandeiras (Myrmecophaga tridactyla) de vida livre e de cati- 
veiro. Dissertação de Mestrado, Faculdade de Ciências Agrárias e Veterinárias, Universidade Estadual Paulista, Jaboticabal, SP. 54p.

Silva E.B., Fioravanti M.C.S., Silva L.A.F., Araújo E.G., Menezes L.B., Miguel M.P. \& Vieira D. 2008. Característica leucocitária, relação albumina/globulina, proteína plasmática e fibrinogênio de bovinos da raça Nelore, confinados e terminados a pasto. Ciência Rural 38:2191-2196.

Silva G.L.S., Silva A.M.A., Nóbrega G.H., Azevedo S.A., Pereira Filho J.M. \& Mendes R.S. 2010. Efeito da inclusão de fontes lipídicas na dieta de cabras em lactação sobre os parâmetros sanguíneos. Ciênc. Agrotecnol. 34:233-239.

Stockham S. \& Scott M. 2011. Fundamentos de Análises Clínicas Veterinárias. Guanabara Koogan, Rio de Janeiro. 719p.

Superina M., Miranda F.R. \& Abba A.M. 2010. The 2010 anteater red list assessment. Edentata 11:96-114.
Thomasset S.C. \& Carter C.R. 2016. Acute pancreatitis. Surgery 34:292300.

Tryland M. 2006. Normal serum chemistry values in wild animals. Vet. Rec. 158:211-212.

Vila L.G. 2015. Midazolam no estresse por contenção em aves silvestres. Dissertação de Mestrado, Escola de Veterinária e Zootecnia, Campus Samambaia, Universidade Federal de Goiás, Goiânia, GO. 72p.

Wendt L.A., Mirek T.C., Santos M.C.I. \& Pedrassani D. 2015. Estudo retrospectivo do atendimento a animais silvestres no hospital veterinário da universidade do Contestado. Anais II Seminário de Pesquisas da Floresta Nacional de Três Barras, Santa Catarina, p.75-76.

West G., Carter T. \& Shaw J. 2014. Edentata (Xenarthra), p.533-537. In: West G., Heard D., Caulkett N. (Eds), Zoo Animal and Wildlife Immobilization and Anesthesia. 2nd ed. Blackwell Publishing, Iowa. 